\title{
AN ANALYSIS OF CHARACTER EDUCATION PRACTICES AS REQUIRED BY CURRICULUM 2013 IN ENGLISH SUBJECT FOR A PILOT PUBLIC ELEMENTARY SCHOOL AT JEMBATAN BUDAYA SCHOOL
}

\author{
A.A.I. Sakanti' ${ }^{1}$ I.W. Suarnajaya ${ }^{2}$, D.P. Ramendra ${ }^{3}$ \\ ${ }^{123}$ English Language Education, Post Graduate Program, Universitas Pendidikan Ganesha, Singaraja \\ e-mail: inten.sakanti.@pasca.undiksha.ac.id, wayan.suarnajaya@pasca.undiksha.ac.id,
} putu.ramendra@pasca.undiksha.ac.id

This study aimed at analyzing the character education practices in an elementary school in Badung to know how the characters were designed, implemented, and assessed as well as analyzing the obstacles encountered by the teachers in integrating character values into their lessons. The data were collected through descriptive case study method involving one English teacher and 38 grade five students. The data were collected through observations, interviews, and document analysis. The findings reveal that character values were not explicitly stated in most lesson plans, however, they are detectable in integration with the learning materials, learning strategies, and learning activities. However, the implementation of the character values seemed ineffective since the focus seemed to scatter around the level of moral action and ignored the moral knowledge and feeling. This means that students were mostly told about what to do with very limited reasons and consequences of the values. It was also found that the assessment for characters was very subjective in nature, since the method used was only an observation.

\section{Keywords: character education, Curriculum 2013, English Subject, piloted elementary} school

\section{INTRODUCTION}

The idea that education should focus on developing good character as well as the pursuit of academic goals is not a new idea (Lickona, 2013). Character education, done early and well, appears to put students on a path toward successful life outcomes, and is therefore an approach to primary prevention is very important. A good character education program establishes a reinforcing system of positive influences that help youth to deal effectively with life and avoid becoming involved in negative behaviors.

According to Lickona (2013), character education is very important to be taught since early age. He stated that character education that has absolute moral value needs to be taught since the early generation so they can understand about the good and correct behavior and attitude.

The character education process is done in three pillars or education, namely family, society, and schools. Family is the first place where the children learn and observe character before they enter school life. Thus, parents' role will pretty much influence the children character development. The way the parents educate the children is very dependent upon the culture where they live. Indonesian culture is well known as a well-deserved reputation for being warm, friendly, and genuine people.

In the school context, an education unit must be a place for initiating, revising, cultivating, and perfecting the character education process. In the function, the teachers have important roles as facilitator, motivator, and educator for the students. In this process, the teachers make an integration of character education in the learning activities. Related to the strategic of character education, (Hidayatullah, 2010), it can be done by modeling, discipline teaching, accustoming, and creating conducive, integrative, situation, and the internalization.

Berkowitz and Bier (2006) found that successful implementation of a character education program requires clear guidelines. Like in Indonesia, the government has 
developed a new curriculum which is call Curriculum 2013 that gives a clear guideline of how the character values are integrated in every subject (Ministry of Education and Culture, 2013). Curriculum 2013 aims to improve the quality of instruction in schools throughout Indonesia, with a specific focus on achieving an optimal balance between the development of cognitive skills and the development of student character.

Elementary school has not only the role to shape students into a cognitively good generation, but also to form the students' attitudes and behaviors in accordance with the guideline applied.

Before conducting teaching and learning process, English teachers are required to design learning preparation, especially character-based instruction lesson plan. According to Ministry of Education and Culture (2013), lesson plan that is designed by English teachers have to consider students' characteristics, encourage students' active participation, develop reading and writing habit, give feedback to the students, accommodate the relevance and cohesiveness of basic competency, learning materials, learning activities, indicators, assessment, and learning resources as a unity component in learning experiences, accommodate integrated learning, and apply information technology and communication.

What have been designed in the character based lesson plan will be implemented by the teachers in classroom learning activities. How the objectives of the lesson plan is in harmony with the activities designed so that at the end of the learning process, the teacher will conduct an assessment to know whether what have been designed and implemented by the teacher is successful or not; to know how fat the students understand about the concept of the character, how the students feel about the character value, and how the students behavior in the classroom which become the realization from their moral knowing and moral feeling. That is why, teachers role is very notable since they will determine the success of the implementation of character-based instruction based on the requirement of Curriculum 2013.

Unfortunately, the implementation of character education through this new curriculum still arise lots of problems from the teachers. According to Mulyaningsih (2015), the Elementary school teachers in Indonesia still find problems in implementing character education in terms of the availability of learning media, the variation of learning method, and the instruments to assess the students' character. She explained that the insufficient number of learning media at school will not make the character education practices run smoothly because media can be used as a tool to develop a particular character. She found also that most of the teachers still do not know how to benefit the media to develop students' character, as a result the teachers only rely on the textbook. She also found that the teachers still do not know how to apply various learning method to foster students' character. In fact, the teachers still employ conventional learning method, like: questions and answer, lecture, discussion, and assignation. Moreover, the teachers still have problem in doing assessment for students' character.

Therefore, from the empirics, the researcher determined to do in-depth investigation about character education practices in terms of designing the character-based lesson plan, implementing character-based instruction, and assessing character-based activities.

In the lesson plan, there are many components that need to be understood by the teachers, like main competency, basic competency, indicators, learning objectives, learning activities, learning media, learning sources, learning material, learning strategy, and assessment. In the implementation, the teachers need to employ three components of good character as proposed by Lickona, (2013), they are: moral knowing, moral feeling and moral action so that the teaching and learning process will be meaningful to term of assessment, the teachers also need to employ authentic assessment that will enable the teachers know exactly the students competency. Therefore, the researcher was also interested in investigating the programs employed by the school to support character education practices as required by Curriculum 2013. Besides, the researcher found it important to investigate the problems encountered by the public elementary school teachers during the implementation of character education. Thus, the researcher believed that this study was different from the 
other studies and was very important to be conducted to reveal new findings related to character education practices as required by Curriculum 2013.

In relation to the implementation of character-based instruction as required by Curriculum 2013, the researcher decided to conduct the research in Badung. The consideration of choosing elementary schools was because the character education in elementary school is given a lot more portion to be concerned than in Secondary school (Ministry of Education and Culture, 2013). The researcher decided to conduct the research in fifth grade because the students in fifth grade has already been settled in the school, they have already been received the exposure of the implementation of the character education practices for four years since the Curriculum 2013 is implemented.

\section{RESEARCH METHOD}

This research is designed in the form of descriptive case study research which mainly analyzes of character education practices in public elementary school at Jembatan Budaya School in Badung Regency. Yin (2014) added that the goal of descriptive case study is to portray precisely a phenomenon where the generality of the phenomenon is the secondary importance.

Therefore, descriptive case study was chosen because the researcher investigated indepth a particular topic that was about the character education practices in term of how the character values were planned in the lesson plan, how the character values were implemented in teaching and learning process, how the assessment of character values were done, and the problems encountered by the fifth grade teachers.

There were three methods of data collection used by the researcher; they were document study, observation and interview. The primary instrument in this research was the researcher and supported by some devices to collect the data, like interview guide, and audio video recorder.

After do data collection process, the data were reducing through the process of sorting data based on the need. At the same time, the researchers do the process of data display. In here, the researcher was display the finding data as the finding of the observation. The last step is conducted the process of conclude: drawing/verifying in which the researcher gave the interpretation about the obtained.

\section{FINDINGS AND DISCUSSION}

Based on the findings on the document study, English Teacher (ET) has designed lesson plans with character values. The character values were: religious, nationalism, independent, communicative and responsible. As Kementerian Pendidikan dan Kebudayaan Republik Indonesia, (2017) states that there are 5 character values that need to be integrated in the teaching and learning process. However, the character value of being accurate is not a part of the 5 character values as proposed by Kementerian Pendidikan dan Kebudayaan Republik Indonesia. Thus, ET integrated 4 character values out of 5 character values. The emerge of those character values was very depending on the learning materials, learning activities, and learning technique designed by the teacher during the two meetings.

As states by Jensen (2001) that lesson plan is an extremely useful tool that serves as a combination guide, resource, and historical document reflecting the teaching philosophy, student population, textbooks, and most importantly, the goals for the students. Therefore, it is very important for English teacher (ET) to design in the lesson plans what character values that will be embedded to the students in the teaching and learning process because lesson plan will guide from the kind of values that will be integrated, how to integrate the values, and what materials and techniques to be used. Thus, without designing the character values in the lesson plans will not make the teaching and learning process successfully achieve the expected competencies.

Besides discussing the character values designed in the lesson plans specifically, it is also essential to discuss each component in the lesson plan, like the subject identify, core competency, basic competency, indicators, learning materials, learning activities, learning 
media, learning sources, and assessment as it is related one to another (Permendkbud, 2014).

Based on the data analysis, it was indicated that the lesson plans included such components, like subject identify, standard of competency, basic competency, learning objectives, learning method, learning activities, learning sources, learning materials, learning media, and assessment. Each of the components in the lesson plans will be described in detail as follows.

Subject identify in both of the lesson plans were designed by ET included such components, like: educational unit, subject, class, semester, and time allocation. In Subject identify, there were not found character values.

Standard competency is the next component in the lesson plans. There was a standard competency in each of LP-1 and LP-2 which was taken from the syllabus developed by the government (see appendix). In LP-1 there was a basic competency which focused on speaking skill "expressing simple instruction or information within a context". There was found communicative character. While the standard competency in LP-2 focused on reading skill "understanding simple English writing in the school context". There was found independence character

The next component in the lesson plans was basic competency. There was one basic competency in LP-1 and two basic competencies in LP-2. In LP-1 the basic competency focused on the speaking skill "having a conservation to ask and give for help or goods politely". There was found communicative character. In LP-2 the basic competency focused on the reading skill "reading the text loudly with correct articulation and intonation" and "understanding the sentences accurately". There was found independence character.

Like what have been found on the standard competency and basic competencies, the learning objectives were also taken from the same syllabus. There were three learning objectives in LP-1, the students were expected to be able to do conversation involving the expressions of asking for a help, giving a help, asking for things, and giving things. In learning objectives, there were found some character values, such as; responsibility, nationalism, and independence characters.

Meanwhile, there were four learning objectives in LP-2, they were: the students were expected to be able to spell words, phrases, and sentences correctly, the students were expected to be able to read words, phrases, and sentences correctly, the students were expected to be able to identify various information in a simple English text. There were also some character values stated on the learning objectives, they were: religious, nationalism, independent, communicative and responsibility characters. Both of LP-1 and LP-2 have the learning objectives in terms of skills and attitude, while the learning objective in terms of knowledge is not stated.

From the source of learning materials, ET also tried to design her own materials to be given to the students. For the first learning material that focused on speaking skill, ET took the materials from the English text book like the example of expressions used in asking and giving help, ET also designed her own material by giving additional expressions that can be used in asking and giving help. In learning materials, there were some character values, such as; communicative, independence, and responsibility characters.

There are some important activities that. what was found on the lesson plan revealed that ET designed the pre-activities by doing several activities, like: praying together before start the learning activities, checking students' attendance, checking students readiness mentally and physically, delivering the learning objectives, brainstorming about the materials that will be discussed, and asking the students to propose their ideas related to the topic on that day. ET missed one activity that was giving the students motivation in learning by telling the benefit of learning this particular material. ET still have problem in designing preactivities as required by Curriculum 2013.

After pre-activities, it is also important to discuss about the design of the whilstactivities that employed scientific approach. It involved five interrelated phases, namely observing, questioning, exploring, associating, and communicating. There were only three main activities in whilst-activities, namely: exploration, elaboration, and confirmation. From 
the design of the learning activities, ET tried to employed several learning techniques, like: role play, group work, discussion, and individual work.

In the lesson plans designed by ET, the researcher could not find any learning models as required by Curriculum 2013. It was because the learning activities in the English lesson plans were very simple and did not really put the students as the centered of the learning process. It was because at the meantime, the government still did not release a rigid format for designing English lesson plans based on Curriculum 2013 considering that English in Elementary level was still an introductory subject.

ET designed several activities for post-activities, in LP-1, there were activities designed as a post-activity, namely: ET revised any mistakes done by the students in terms of the pronunciation while the students practice the conversation. ET asked the students to present the dialogue in front of the class, and ET gave verbal reinforcement, like: well done, very good, good job to motivate the students to be brave in presenting something later on. In here, ET should do a reflection part towards what have been learnt during the day and summarize the material on that day so that the students will end up with a very clear concept. ET must also give an enrichment exercises to the students to be done at home as required by Curriculum 2013. While in LP-2, ET only designed an activity that was by asking the students to relate what have been learnt with the real life situation. As the text that they learnt was related to Present Continuous tense, so the students were asked to make a simple sentence about any activities happening in the classroom.

The lesson plans that have been designed by the Grade 5 teachers were used as a basis in implementing the teaching and learning process in the classroom. The activities included pre-activities, whilst-activities, and post-activities. English Teacher (ET) conducted pre-activities, whilst-activities, and post-activities in the teaching and learning process.

ET did pre-activities by praying together, checking students' attendance, checking students' readiness in learning, delivering the learning objectives, doing a little bit of brainstorming by asking the students related to the topic that are going to be discussed. Thus it indicated that ET did not conduct any activities to motivate the students to learn about today's topic or in other words they did not tell the benefit of learning the materials. It can be concluded that ET still have problems in conducting pre-activities based on the requirement of Curriculum 2013.

Besides the relevancy of the steps in doing pre-activities with Curriculum 2013, it is also important to discuss the character values integrated during pre-activities, it was found that ET tried to integrate some character values through pre-activities, namely: religious, Nationalism, Independent, Communicative, and Responsible.

Whilst- activities were divided into five phases, such as observing, questioning, exploring, associating, and communicating. Basically, ET conducted a simpler steps in teaching and learning process that consist of exploration, elaboration, and confirmation that belongs to the previous Curriculum School Based Curriculum.

Post-activities are done before closing the lesson. In post-activities of the first implementation, ET did a post activities by giving feedback towards students' performances then ET together with the students summarize the lesson, and saying good bye. In the second observation ET did post activity by relating have been learnt with the daily life situation, like: ET asked the students to make a simple sentence about the activity in the classroom.

The Assessment is the last part in the lesson plan. Based on the document analysis, English Teacher (ET) has designed the assessment for character values, ET used scoring rubric to assess the students' attitude by using Likert Scale and teacher's note. From the result of the observation in the classroom learning activities, ET conducted any assessment for the students' behavior by writing any evidence on the teacher's note.

Based on the result of the document study, it was found that the teacher had problem in designing character values in the lesson plan. She did not state any character values in basic competency and indicators.

Based on the result of the interview, ET admitted that she found any difficulties in inserting character values in the teaching and learning process as English is only given a 
small portion of time allotment. So, it is quite difficult to teach the material and at the same time integrate some character values. This lack of organization from the teacher will cause the ineffectiveness of the character values insertion in the teaching and learning. This type of character education is expected to be able to build a strong character education at school.

\section{CONCLUSION AND SUGGESTIONS}

Based on the findings and discussions, the researcher concluded some points related to the character education practices at piloting elementary school in Badung Regency as required by Curriculum 2013.

1. The English lesson plans of Curriculum 2013 consisted of subject identify, core competency, basic competency, indicators, learning objectives, learning materials, learning method, learning activities, learning media, learning sources, and assessment. However, the formulation of subject identify was not involving the character aspect. The learning materials designed have loaded with character values. The learning activities and learning strategies in the lesson plans have also designed to help the students show their positive behavior. However, some of the learning materials were not relevant with the activities; for example, in the questioning activities the learning material required the students to answer questions instead of letting the students to formulate questions to arise their critical thinking.

2. The implementation of the character-based instruction was done by considering the program of Friendly Child based School where the teachers should model positive behavior to the students which was a good program in building the students' character. The teacher also kept reminding the students to show positive behavior stated on the teacher-students agreement. However, the teacher admitted that they were lack of competence and experience in employing the learning materials, learning activities, and learning strategies optimally to teach characters. The teacher was likely to jump directly to moral action without stating explicitly what characters are expected from the students. The teacher did not fill in the cognitive of the students by telling the meaning of the characters expected. The teacher did not also touch the students' feeling by reading literatures, stories, or autobiography. Therefore, the character education seemed not implemented really well because moral knowing and moral feeling steps seemed to be skipped. It is likely that the teacher instructed the students to do something without informing the expected characters from the students.

3. The teacher assessed the students' character through observation and journal. However, the teacher needs to elaborate more methods, like: self-assessment and peerassessment to get a more authentic data regarding the students' behavior.

4. There were several problems faced by the teacher in the implementation of Curriculum 2013. The problems found were in terms of designing character values in the lesson plan, implementing character values through learning strategies, learning media, and learning activities, and assessing character values authentically. It was due to lack of understanding and clear guidelines regarding character education practices.

The school needs to provide models of character education practices since there are still problems in designing lesson plan, its implementation, and the assessment. The school needs to give a clearer concept on how to design a character-based lesson plan, how to implement a character-based lesson, and how to conduct a character-based assessment.

The teachers need to adopt character values through some components in the lesson plan, elaborate various strategies to boost the students' character and know exactly how to cultivate the students' positive behavior through moral knowing, moral feeling, and moral action. The teachers also need to learn how to make the students become more active in the classroom as one of the characteristics of the current curriculum that emphasized on the paradigm of student-centered learning. At last, the teachers need to employ different methods to assess the students' character authentically.

The other researchers need to conduct a more holistic research on character education practices that involves the activities outside the classroom, such as: parent involvement, community involvement, and extracurricular to support the character education 
practices inside the classroom. So that, more facts or information can be explored and gathered.

\section{REFERENCES}

Almerico, G. M. (2014). Building character through literacy with children's literature. Research in Higher Education Journal Volume 26. University of Tampa.

Berkowitz, M. W., \& Bier, M. C. (2006). "What Works in Character Education: A ResearchDriven Guide for Educators," Character Education Partnerships.

Brown, H. D. (2001). Teaching by Principles: An Interactive Approach to Language Pedagogy 2nd Edition. New York: Addison Wesley Longman, Inc.

Clark, F. P. (2014). With liberty and Justice for All Character Education for America's Future. Journal of Character Education, 10(1), 31-36.

Darmansyah, A. (2014). The Development of Character Education Curriculum for Elementary Student in West Sumatera. International Journal of Education and Research, 2(6), 189-198.

Djailani, A. (2013). Strategy Character Building of Students at Excellent Schools in the City of Banda Aceh. Journal of Research \& Method in Education, 1(5), 49-59.

Denzin, N. and Lincoln, Y. (ed). (1994) Handbook of Qualitative Research, Sage Publications.

Dhindsa (2007). Upper Secondary Bruneian Science Students' Perceptions of Assessment. International Journal of Science Education, 29(10), 1281-1280. Diaz-Rico, L. T., \& Weed,

Faridi, A (2014). The Difficulties of English Teachers in Instilling Character Building Through Narrative Stories at Elementary Schools, Indonesia. International Journal of Contemporary Applied Sciences, 12

Freeks, F. E. (2015). The influence of role-players on the character-development and character-building of South African college students. South African Journal of Education. 35(3)

Freeman, G. (2013). The Implementation of Character Education and Children's Literature to Teach Bullying. Characteristics and Prevention Strategies to Preschool Children: An Action Research Project. DOI 10.1007/s10643-013-0614-5

Gay, L. R.s Geoffrey, E. M., \& Peter, A. (2009). Educational research: Competencies for analysis and applications. USA: Person.

Gharuty, F. A. (2009). Studi dokumen dalam penelitian kualitatif. Retrieved from http://adzelgar.wordpress.com/2009/02/02/studi-dokumen-dalam-penelitian-kualitatif/

Han, H. S., \& Thomas, M. S. (2010). No child misunderstood: Enhancing early childhood teachers' multicultural responsiveness to the social competence of diverse children. Early Childhood Education Journal, 37(6), 469-476.

Hidayati, A. (2014). The Development of Character Education Curriculum for Elementary School in West Sumatera. International Journal of Education and Research, 2(6).

Hidayatullah, F. (2010). "Pendidikan Karakter: Membangun Paradaban Bangsa”. Surakarta: Yuma Pustaka

Jensen, L. (2001). Planning Lessons. In M. Celce-Murcia (Ed), Teaching English as a Second or Foreign Language ( $3^{\text {rd }}$ edition, pp 403-413). Boston: Heinle \& Heinle.

Katilmis, A., Eksi, H. \& Ozturk, C. (2011). Efficiency of social studies integrated character education program. Educational Sciences: Theory \& Practice 11 (2), 36-50. 
Kementerian dan Pendidikan dan Kebudayaan Republik Indonesia (2017). Konsep dan Pedoman Penguatan Pendidikan Karakter

Lickona, T. (2013). Pendidikan karakter: Panduan lengkap mendidik siswa menjadi pintar dan baik. Bandung: Penerbit Nusa Media

Lockwood, A. (2009). The case for character education: A developmental approach. New York, NY: Teacher's College Press.

Mark, W. S. (2014). Evaluation of a Moral and Character Education Group for Primary School Students. Discovery - SS Student E-journal. Vol, 142-164.

McDonough, J. and McDonough, S., (1997). Research Methods for English Language Teachers, London: Arnold.

McElmeel, S. L. (2002). Character Education: A book guide of teachers, librarians, and parents. Greenwood Village, CO: Teacher Ideas Press.

Miles, M. B., \& Huberman, A. M. (1994).Qualitative data analysis: An expanded source book (2nd ed.). Thousand Oaks, CA: Sage.

Ministry of Education and Culture. (2013). Salinan lampiran Peraturan Menteri Pendidikan dan Kebudayaan Republik Indonesia Nomor 65 Tahun 2013 tentang Standar Proses Pendidikan Dasar dan Menengah. Retrieved from http://bsnp-indonesia.org/wpcontent/uploads/2009/06/03.-A.-Salinan-Permendikbud-No.-65-th-2013-ttg-Standar-

Proses.pdf

Mulyaningsih, I. (2015). Implementasi pendidikan karakter pada pembelajaran tematik di kelas iv sd negeri prembulan galur kulon progo.

Moleong. (1998). Metodologi penelitian kualitatif. CV. Bandung: Remaja Rosdakarya.

Nzekwu, I. (2016). Language education for character and skill development in Nigeria. AFRREV IJAH: An International Journal of Arts and Humanities, 5(3).

O'malley, J. M. \& Pierce (1996). Authentic assessment for English language learners. United States of America: Addison-Wesley.

Pala, A. (2011). The Need for Character Education. International journal of social sciences and humanity studies, 3(2 (2011)), 23-32. Retrieved from http://www.sobiad.org/ejournals/journal_ijss/arhieves/2011_2/aynur_pala.pdf

Pearson, Q. M., \& Nicholson, J. I. (2000). Comprehensive character education in the elementary school: Strategies for administrators, teachers, and counselors. Journal of Humanistic Counseling, Education \& Development, 38, 243.

Richard, Jack C. (2013) Curriculum Development in Language Teaching, New York: Cambridge University Press.

Russell, B. W. \& Waters, S. (2013). Using Film to Promote Global Citizenship.

Ryan, K. (1999). Mining the values in the curriculum. National Education Association, Retrieved January 8, 2018 from http://ww.nea.org.

Suharjo. (2006). Mengenal Pendidikan Sekolah Dasar. Jakarta: Departmen Pendidikan Nasional Direktorat Jenderal Pendidikan Tinggi dan Direktorat Ketenagaan.

Tyra, C. (2012) Bringing books to life: Teaching character education through children's literature. Rising Tide, 5, 1-10

Undang Undang Sistem Pendidikan Nasional, $2003 . \quad$ http:// www.lin.go.id/dokumen/230703r940001/uu_sis1.htm.

Wibowo, A. (2012). Pendidikan karakter strategi membangun karakter bangsa berperadaban. Yogyakarta: Pustaka Pelajar. 
Widyahening, E. T., \& Wardhani, N. E. (2016). Literary Works and Character Education. International Journal of Language and Literature. 4(1)

Williams, H. (2010). Widening the lens to teach character education alongside standards curriculum: The clearing house, 83, 115-120

Woodward, T. (2001).Planning Lessons and Courses: Designing Consequences of Work for the Language Classroom. Cambridge: Cambridge University Press.

Wyne, E. \& Ryan, K. (1997).Reclaiming our schools: Teaching character, academics, and discipline. Upper Saddle River, NJ: Prentice Hall.

Yin, R. (2014), Case Study Research: Design and Methods, $5^{\text {th }}$ edition (first edition, 1984), Sage, Los Angeles.

Zakin, A. (2012). Hand to hand: Teaching tolerance and social justice on child at a time. Childhood Education, 88(1), 3-12. 